Relato de Caso / Case Report

\title{
Isolated trisomy 11 in de novo acute myeloid leukemia
}

\section{Trissomia 11 isolada em leucemia mielóide aguda de novo}

Everson A. Krum

Tatiane Hamed

Mihoko Yamamoto

Maria de Lourdes Chauffaille
The real mechanism involved in trisomies and leukemogenesis remains unknown and more information about this connection is essential, but unfortunately the clinical outcome and hematological profile of patients with isolated trisomy 11 and AML have not been well characterized. Considering the limited data on the specific disease entity, the current report describes two cases of de novo acute monocytic leukemia (AMoL) and isolated +11 , in which this event was further characterized. Rev. bras. hematol. hemoter. 2008;30(3):253-255.

Palavras-chave:Trisomy 11; acute myeloid leukemia; chromosomes.

\section{Introduction}

Chromosomal trisomies are characterized by an additional copy of genomic material. Isolated trisomies $(+8,+11,+13,+21)$ comprise $90 \%$ of all trisomies ${ }^{1}$ and $7 \%$ of adult de novo acute myeloid leukemia (AML). ${ }^{2}$ Little is known about the clinical and hematological characteristics of de novo acute monoblastic leukemia (AMoL) patients with isolated trisomy 11 , but immunophenotypic studies have shown that trisomy 11 and AML are associated with an early myeloid precursor, ${ }^{3}$ probably as a result of a pluripotent stem cell disorder being discovered in primary as well as in secondary myelodysplastic syndromes (MDS)/AML. Sierra and coworkers ${ }^{3}$ proposed that de novo AML with trisomy 11 can be considered a specific entity associated with poor outcomes and characterized by morphology of blasts cells with myelodysplastic characteristics. Concerning cytogenetic results, isolated trisomy 11 is the third most common isolated trisomy in de novo AML, reported in 5.7\% of AML patients with normal karyotypes, $37.5 \%$ of cases with trisomy 11 and other cytogenetic abnormalities and $79 \%$ of cases with trisomy as the sole karyotypic abnormality. ${ }^{4}$ In AML or MDS isolated trisomy 11 occurs in less than $3 \%$ of all cases ${ }^{4-7}$ often with no full description of clinical and hematological features. ${ }^{8}$

Besides +11 , abnormalities involving chromosome 11, translocations, interstitial deletions and duplications are reported in various hematologic disorders, especially MLL Partial Tandem Duplication (MLL - PTD), which confers, both in childhood and adult AML, a worse prognosis and shortened overall and event free survival. ${ }^{9}$ Molecular studies of AML with trisomy 11 have revealed a high incidence of partial tandem duplication of the $M L L$ gene $^{11}$ but it is still uncertain how MLL gene duplication and trisomy 11 arise and how they are related during leukemogenesis. The aim of this report is to describe, with clinical and laboratory data, two cases of isolated trisomy 11 and de novo AMoL, to provide more information about this event.

\section{Case history and results}

Case 1

A 59 year-old female patient was admitted to hospital in February 2000 due to fever, fatigue and weight loss. Routine blood analysis showed anemia (hemoglobin $5.2 \mathrm{~g} / \mathrm{dL}$ ), white blood cell count (WBC) of $0.31 \times 10 \% / \mathrm{L}$ with $82 \%$ of blast cells and $12.6 \times 10^{9} / \mathrm{L}$ platelets. Bone marrow aspiration presented $92 \%$ of monoblasts and immunophenotyping showed: positive CD11c, CD13, CD14, CD15, CD33, CD38, CD45, CD65 and HLA-DR. Bone marrow karyotype showed 47,XX,+11[5]/ $46, \mathrm{XX} .{ }^{12}$ The diagnosis of AMoL (poorly differentiated) by $\mathrm{WHO}^{13}$ or AML M5a according to the $\mathrm{FAB}^{14}$ classification was established. The patient was scheduled to a Dauno +

Disciplina de Hematologia e Hemoterapia - EPM - Universidade Federal de São Paulo (Unifesp) - São Paulo-SP.

Correspondence: Maria de Lourdes Chauffaille

Rua Botucatu, 740, $3^{\circ}$ andar - Vila Clementino

04023-9000 - São Paulo-SP - Brasil

Tel: (11) 5579-1550; fax: (11) 5571-8806

E-mail chauffaill@hemato.epm.br 
AraC $(3+7)$ regimen but complete remission was achieved only after a second induction with AraC, VP16 and Mitoxantrone. Consolidation was achieved with the last regimen at the same doses. Intensification was not considered due to the frail aspect (low Karnofsky index) of the patient, but a maintenance regimen with Ara-C for 15 months was administered. Seventeen months out of therapy the patient relapsed and died due to sepsis.

\section{Case 2}

A 54 year-old female patient was admitted to the hospital because of abdominal pain, sickness, watery diarrhea and skin infections in February 2001. She presented hepatomegaly $(8 \mathrm{~cm})$. Blood analysis showed anemia (hemoglobin $6.7 \mathrm{~g} / \mathrm{dL}$ ), WBC was $3.99 \times 10^{9} / \mathrm{L}$ with $87 \%$ of blasts and $1.09 \times 10^{9} / \mathrm{L}$ platelets. Bone marrow aspiration showed $88 \%$ of monoblasts and immunophenotyping showed positive CD4, CD11c, CD13, CD15 and CD33. Bone marrow karyotype revealed $47, \mathrm{XX},+11 / 46, \mathrm{XX}^{12}$ The diagnosis of AMoL, poorly differentiated by $\mathrm{WHO}^{13}$ or AML M5a FAB ${ }^{14}$ was made. The patient developed respiratory insufficiency and died before the start of chemotherapy.

\section{Discussion}

Patients with trisomy 11 and AML are associated with short first complete remission and poor response to subsequent chemotherapeutic regimens. ${ }^{6,15}$ Due to the variable clinical course and prognosis, they may be included in the intermediate cytogenetics risk group for success of induction and overall survival ${ }^{16}$ or in the unfavorable risk group. ${ }^{17}$ It is currently unknown whether isolated trisomy 11 constitutes an independent prognostic factor. This numerical chromosome change is not correlated with any specific WHO subgroup of MDS/AML, despite, in previous studies, trisomy 11 has been associated with older age, M2 and M1 FAB subtypes, high platelet count, low incidence (13-15\%) of patients with WBC counts $\left(>50 \times 10^{9} / \mathrm{L}\right)$ and short long term disease free survival, ${ }^{4}$ it has been suggested that +11 is especially associated with myelomonocytic proliferation. ${ }^{6}$

The patients here presented AMoL FAB M5, white blood cell count $>20.000 \times 10^{9} / \mathrm{L}$, platelet count $>10 \times 10^{9} / \mathrm{L}$ and were more than 50 years old. Acute monoblastic leukemias (M5a and M5b) are considered aggressive diseases due to their association with hyperleukocytosis, extra medullar and gingival or cutaneous infiltration. ${ }^{6}$ These cases represented $1.3 \%(2 / 154)$ of all the AMLs admitted to the Department of Hematology - Unifesp from 1995 to 2005. In studies, the incidence ranges from $0.9 \%$ to $0.76 \%$ as the sole abnormality. ${ }^{3,4}$

Approximately $90 \%$ of adults with sole +11 and AML and $11 \%$ of adult patients with de novo AML and normal cytogenetics carry a molecular rearrangement of the $M L L$ gene (mixed lineage leukemia or myeloid/lymphoid leukemia). ${ }^{7}$
This rearrangement occurs in the early phase of the disease and is not a genetic event induced by chemotherapy. ${ }^{18}$ Caligiuri and colleagues ${ }^{7}$ did not find additional mutated $M L L$ genes in AML with trisomy 11 and proposed that the extra copy of chromosome 11 containing the wild type allele provides a selective growth or survival advantage over normal cells. ${ }^{19}$ This is provocative and warrants further molecular investigations of AML with trisomy 11 and the $M L L$ gene, as this may give useful information on the genetic mechanisms leading to the formation of trisomies during leukemogenesis.

\section{Resumo}

O mecanismo envolvido em trissomias e leucemogênese permanece não esclarecido e mais dados sobre esta relação são fundamentais, mas infelizmente os resultados clínicos e o perfil hematológico dos pacientes com trissomia 11 isolada e LMA ainda não foram bem caracterizados. Considerando o limitado número de informações, este relato descreve dois casos de leucemia monocítica de novo e trissomia 11 onde este evento foi caracterizado. Rev. bras. hematol. hemoter. 2008;30(3):253-255.

Palavras-chave: Trissomia 11; leucemia mielóide aguda; cromossomos.

\section{References}

1. Farag SS, Archer KJ, Mrozek K, Vardiman JW, Carrol AJ, Pettenati MJ et al. Isolated trisomy of chromosomes 8, 11, 13 and 21 is an adverse prognostic factor in adults with de novo acute myeloid leukemia: results from Cancer and Leukemia Group B 8461. Int J Oncol. 2002;21(5):1041-51

2. Bloomfield CD. Clinical importance of genetics findings in adult AML. Int J Hematol. 2002;76(Suppl 2):176-7.

3. Sierra M, Hernandez JM, Garcia JL, Gutierrez NC, Perez JJ, Vidriales MB et al. Hematological, immunophenotypic, and cytogenetic characteristics of acute myeloblastic leukemia with trisomy 11. Cancer Genet Cytogenet. 2005;160(1):68-72.

4. Heinonen K, Mrozek K, Lawrence D, Arthur DC, Pettenati M, Stamberg $\mathrm{J}$ et al. Clinical characteristics of patients with de novo acute myeloid leukaemia and isolated trisomy 11: a Cancer and Leukemia Group B study. Br J Haematol. 1998;101(3):513-20.

5. Slovak ML, Traweek ST, Wilman CL, Head DR, Kopecky KJ, Magenis RE et al. Trisomy 11: an association with stem/progenitor cell immunophenotype. Br J Haematol. 1995;90(2):266-73.

6. Bernasconi P, Cavigliano PM, Boni M, Malcovati L, Astori C, Castagnola $\mathrm{C}$ et al. Trisomy 11 and a complex $\mathrm{t}(11 ; 11 ; 22)$ in a Patient with acute myelomonocytic leukemia (AML-M4) following myelodysplasia (MDS): A cytogenetic study of a mechanism of leukemogenesis. Cancer Genet Cytogenet. 2000; 116(2):111-8.

7. Caligiuri MA, Strout MP, Oberkircher AR, Yu F, de la Chapelle A, Bloomfield CD. The partial tandem duplication of ALL1 in acute myeloid leukemia with normal cytogenetics or trisomy 11 is restricted to one chromosome. Proc Natl Acad Sci USA. 1997; 94(8):3899-902

8. Zhu Y, Xue Y, Pan J, Wu Y, Lu D. Clinical and cytogenetic studies of hematological malignancies with isolated trisomy 11. Zhonghua Xue Ye Xue Za Zhi. 2002;23(8):425-7. 
9. Jadhav M, Cushing B, Ozdemir O, Mohamed A, Ravindranath Y, Savasan S. Clonal trisomy 11 in a child with acute leukemia: G Banding vs. FISH. Med Pediatr Oncol. 2001;37(5):475-6.

10. Bassecke J, Whelan JT, Griesinger F, Bertrand FE. The MLL partial tandem duplication in acute myeloid leukaemia. Br J Haematol. 2006;135(4):438-49.

11. Schichman SA, Caligiuri MA, Strout MP, Carter SL, Gu Y, Canaani $\mathrm{E}$ et al. ALL-1 partial tandem duplication in acute leukemia. Proc Natl Acad Sci USA. 1994;91(13):6236-9.

12. Mitelman F (1995). An International System for Human Cytogenetic Nomenclature (ISCN). Karger, Basel, Switzerland.

13. Jaffe ES, Harris NL, Stein H, Vardiman JW (2001). World Health Organization Classifications of Tumours. Pathology and Genetics of Tumour of Haematopoietic Tissues. IARC Press, Lyon, France.

14. Bennet JM, Catovsky D, Daniel MT, Flandrin G, Galton DA, Gralnick HR et al. Proposed revised criteria for the classification of acute myeloid leukemia: a report of the French-AmericanBritish Cooperative group. Ann Intern Med. 1985;103(4):620-5.

15. Kwong YL, Wong KF. Acute myeloid leukemia with trisomy 11: a molecular cytogenetic study. Cancer Genet Cytogenet. 1997;99 (1):19-23

16. Byrd JC, Mrózek K, Dodge RK, Carrol AJ, Edwards CG, Arthur DC et al. Pretreatment cytogenetic abnormalities are predictive of induction of relapse, and overall survival en adult patients with de novo acute myeloid leukemia: results from Cancer and Leukemia Group B (CALGB 8461). Blood. 2002;100(13):4325-36.

17. Pelloso LAF, Chauffaille MLLF, Ghaname FS, Yamamoto M, Bahia DMM, Kerbauy J. Cariótipo em leucemia mielóide aguda: importância e tipo de alteração em 30 pacientes ao diagnóstico. Rev Assoc Med Bras. 2003;49(2):150-5.

18. Yamamoto K, Hamaguchi H, Nagata K, Kobayashi M, Taniwaki M. Tandem duplication of the MLL gene in myelodysplastic syndrome derived overt leukemia with trisomy 11. Am J Hematol. 1997;55(1):41-5.

19. Ayton PM, Cleary ML. Molecular mechanisms of leukemogenesis mediated by MLL fusions proteins. Oncogene 2001;20(40):5695707.

Avaliação: Editor e dois revisores externos

Conflito de interesse: não declarado

Recebido: 06/11/2007

Aceito: $21 / 02 / 2008$ 